DOI: 10.15503/onis2014-202-211

\title{
SAKRALIZACJA CIAEA. ZWIĄZKI EROTYKi I MISTYKI W POEZJI BOgUSŁaWA KierCA
}

\author{
Edyta Sołtys-Lewandowska, edyta_soltys@wp.pl \\ Uniwersytet im. A. Mickiewicza \\ Ul. Wieniawskiego 1, 61-712 Poznań
}

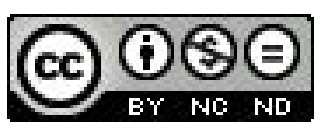

\section{STRESZCZenie}

Artykuł prezentuje interpretację poezji Bogusława Kierca w kontekście filozoficznych odniesień do ciała, mistycyzmu chrześcijańskiego i komunii, postsekularnej teorii nagości Georgia Agambena oraz kategorii epektasis. Występujące w tej poezji elementy, jak „wychylanie się z ciała” czy erotyzacja osoby Chrystusa są transgresją przeciw schematom zachowań religijnych w celu poszukiwania nieograniczonej jedności z Bogiem, łącznie z poetyką sakralizacji ujawniają dążenie twórczości B. Kierca do podkreślania wartości ciała i seksualności w doświadczeniu religijnym i możliwości tego doświadczenia w nowoczesności.

Słowa kluczowe: współczesna poezja religijna, sakralizacja, sacrum, mistyka, erotyzm, epektasis, postsekularyzm

Sacralization of the body. The relationships between eroticism and mysticism in the poetry of Bogusław Kierc

\section{Abstract}

The article presents the interpretation of the poetry of Bogusław Kierc in the context of philosophical references to the body, Christian mysticism and Communion, Agamben's post-secular theory of nudity and the category of epektasis. Such elements of Kierc's poetry as 'leaning out of one's body' and erotization of Christ constitute the transgression against religious behavioral patterns in an attempt to achieve absolute unity with God. Together with the poetics of sacralization, they reveal Kierc's artistic attempt to emphasize the importance of the body and sexuality in a religious elevation and the possibility of experiencing it in the times of modernity.

Key words: religious contemporary poety, sacralization, sacrum, mystic, erotism, epektasis, postsecularism

Cielesność należy do tych kategorii, które w nowoczesności (zainicjowanej w tym kontekście przez Fryderyka Nietzschego i Zygmunta Freuda) znajdują się w centrum rozważań i poddawane są nieustannym reinterpretacjom. Ciało jest „wehikułem bycia w świecie" ${ }^{\prime \prime}$, pisał twórca fenomenologii ciała Maurice Merleau-Ponty, , a mieć ciało to dla żyjącej istoty wiązać się z określonym środowiskiem, utożsamiać się z pewnymi projektami i stale się angażować"2. Somatyczność wpisuje się również w ciągle aktualne polemiki o kształt modernizmu. Włodzimierz Bolecki podkreślał, że poza różnymi cechami tej szeroko rozumianej formacji kulturowej, jak przełamywanie różnego rodzaju tabu czy prowokacyjność, znajduje się także refleksja nad podmiotowościa, zwłaszcza zaś uwzględnienie cielesności w kształtowaniu tożsamości człowieka. ${ }^{3}$

Poza kontekstem filozoficznym i modernistycznym, dla których odkrycie oraz eksploracja cielesności i seksualności było fundamentalne, ludzkie corporum stanowi również ważny problem w sferze pytań o sacrum i profanum. Kwestie te dotyczą zarówno samego problemu przedstawiania ciała, który choćby dzięki sztuce abject wkracza w coraz to nowe obszary, jak i kontekstów mówienia o nim (zwłaszcza opozycja: naturalne-kulturowe). Z jednej strony dezawuują one podział na sacrum i profanum, z drugiej - to w ciele, źródle godności i tożsamości człowieka, szukają śladów transcendencji lub znamion sakralności mu przydają. Rodzące się pytania o miejsce ciała, są pytaniami natury filozoficznej i teologicznej.

Sakralizacja (uświęcanie, uwznioślanie) ciała, a także sfer związanych z ludzką cielesnościa, jest zgodna z biblijnym przekazem (człowiek stworzony na obraz i podobieństwo Boga), a mimo to słabo obecna w potocznej świadomości religijnej (dominujący manicheizm). Zostaje ona na nowo wykorzystana przez poezję, która dla tego typu przedstawiania ciała, szuka nie tylko uprawomocniania w kontekstach stricte religijnych (biblijnych, mistycznych, teologii ciała), co równie skutecznie ślady sacrum odnajduje w codzienności i w ludzkich doświadczeniach.

1 M. Merleau-Ponty, Fenomenologia percepcji, Warszawa 2001, s. 227.

2 Tamże.

3 W. Bolecki, Modernizm w literaturze polskiej XX wieku, [rekonesans], „,Teksty Drugie” 2000, s. 4, $22-23$. 


\section{„WYCHYLANIE SIĘ Z CIAŁA"}

Ciekawie problematyka sakralizacji przedstawia się w poezji (obfitej i różnorodnej) wrocławskiego poety Bogusława Kierca. Jego twórczość niepokoi przedziwnym splotem erotyki i wiary. Wielkimi tematami tej poezji są: ciało, erotyzm, Bóg, ukazane jako punkty styczne różnych ludzkich doświadczeń. Zarówno ciało, jak i dusza są tu erotyczne. Erotyczne, czyli, tak jak u Georgesa Battaille'a czy Oktavio Paza, sprzeciwiające się zwierzęcemu seksualizmowił. W twórczości Kierca erotyzm staje się metaforą życia, niekiedy ekstatycznego, sycącego się możliwością seksualnego spełnienia, innym razem świadomego własnych ograniczeń (cielesnych, społecznych), ale także i wiary: miłości do Boga spalającej się w ogniu namiętności. Erotyzm jest tym, co w poezji autora Cła łączy zarówno duszę, jak i ciało. Oba te obszary, o fundamentalnym dla człowieka znaczeniu, tylko ujawniając wzajemną zależność umożliwiają właśnie „bycie człowiekiem”. Paradoksalnie zbliża to twórczość wrocławskiego poety do tez G. Bataille'a : „(...) doświadczenie erotyczne jest bliskie świętości. (...) oba doświadczenia są skrajnie intensywne. Kiedy mówię o świętości, mam na uwadze życie określone przez obecność w nas jakiejś rzeczywistości świętej, która może wstrząsnąć naszą najgłębszą istotą"5.

Bohater twórczości Bogusława Kierca, poszukujący intymnego zjednoczenia zarówno z drugim człowiekiem jak i z Bogiem, "wychyla się z ciała”, objawiając nieograniczoną zachłanność bycia, możliwą jedynie w „aktywnie zmysłowym" kontakcie ${ }^{6}$. Jest to właśnie owym skrajnie intensywnym doświadczeniem, wstrząsającym, wytrącającym z biegu codziennych doświadczeń, jak w wierszu Wiara?.

„Bycie poza ciałem” to wciąż nie dość zaspokojona potrzeba bohaterów poezji Kierca. Wyjście z siebie, pewna szczególna transcendencja, udowadnia, że człowiek potrzebuje zmysłowego kontaktu, potrzebuje „mojej skóry”, „myśli i wnętrzności”. Cała ta cielesność buduje opozycję doświadczenie-wiara. O ile, jak ukazuje przywołany utwór, wiara jest olśnieniem, błogosławieństwem pewności bez „niewidzenia”, o tyle kontakt z Innym wymaga uruchomienia zmysłów. "Ciało jest jedyną struktura, przez którą mogę poznać Innego"8. Sam Kierc komentuje to w ten sposób: „To, co nazywam wrażeniem »wychylania się« z ciała dotyczy tak zwanego mojego ciała. Tak zwanego, bo nie wiem, jak szeroko istnieje mojość ciała, czy zakres zmysłowej ekspansji i przestrzeń myślenia teżjest tym moim ciałem. Powiedzmy, że jest. I że to moje styka się z nie moim. Zazwyczaj dopiero to zetknięcie daje mu odczuć moje i nie moje, choć to nie moje natychmiast staje się moje - w moim doznaniu i pomyśleniu - na granicy zetknięcia. (...) twoje ciało (albo, gdy mówię o Tobie: Twoje), kiedy je przyjmuję czy odpycham, jest właśnie ograniczone przez moje ciało" ${ }^{\prime \prime}$.

Ciało zatem, nie tyle znaczy samo w sobie, ale dzięki swojemu otwarciu na doświadczanie Innego, dzięki zmysłom i cielesnej percepcji, staje się bramą poznania. Stąd niejako każde doświadczenie cielesne jest doświadczeniem granicznym, w tym sensie, że przekracza granice „mojości”, zaczynając od ciała, wkracza do świadomości, myślenia, staje się doświadczeniem w pełni egzystencjalnym. Znamienne jest to, że w poezji Kierca istnieje silny dualizm, zarówno w przeciwstawianiu sobie ciała i duszy, materii i ducha, jak i w podejściu do samej fizyczności. Niezwykle bliskie jest mu z ducha platońskie spojrzenie na ciało jako więzienie duszy, tym samym deprecjonowanie i wręcz negowanie wartości własnej fizyczności (z biegiem lat również uzupełnione o kontekst starzenia się ciała): „dusza oblepiona obłoconym ciałem”10, „obmyty z prochu/ ciała/ do czystego tchnienia" ${ }^{\prime \prime 1}$, ,by mu wystrugał, gdy duszyczka zbrzydła,/ dla mdłego ciała szczudła albo skrzydła" ${ }^{\prime 2}$. Dla ciała zarezerwowane są więc telluryczne epitety, silnie konotowane z biblijnym „prochem ziemi", przywołujące tym samym topos vanitas. Gdyby jednak poprzestać jedynie na tych uwagach, nie byłoby w poezji Kierca nic wykraczającego ponad kilka przez wieki powielanych biblijno-barokowych toposów. Mimo tak licznych przykładów na wiarę w dualizm cielesno-duchowego człowieka, twórczość autora Cła naznaczona jest zarazem pewnym niedosytem wobec tych ustaleń. Podmiot tej poezji, uwikłany we własną cielesność, seksualność, ale i potrzebę transcendencji, jest podmiotem, który niejako na własnej „skórze” doświadcza niejasności i „płynności” obu tych kategorii:

4 "Erotyzm jest aktywnością seksualną człowieka o tyle, o ile różni się od aktywności zwierząt. Aktywność seksualna człowieka niekoniecznie musi być erotyczna. Staje się erotyczna, ilekroć przestaje być elementarna, zwierzęcą seksualnością". G. Bataille, Erotyzm, Gdańsk 2007, s. 31.

5 G. Bataille, Śzwietość, erotyzm i samotność, [w:] M. Janion, Z. Majchrowski (red.), Transoresje, T. 2, Gdańsk 1982, s. 349.

6 B. Kierc, Bazgroty dla składacza modeli latajacych, Szczecin, Brzeszcze 2010, s. 16.

7 Tenże, Wiara, [w:] Tenże, Plankton, Wrocław 2006, s. 51.

8 M. Sarnińska-Górecka, Ciało jako ontyczny fundament podmiotowości, Toruń 2012, s. 184.

9 Tamże.

10 Tenże, Raz na zawusze, Wrocław 1997, s. 5

11 Tamże, s. 22.

12 Tenże, Zaskroniec, Wrocław 2003, s. 9 


\author{
"I(...) dusza $(. .$. \\ która jest, jak być powinna - \\ tyle stała, ile płynna; \\ nie wiem, czy wtopione w stałość \\ duszy - w duszy pływa ciało, \\ czy w płynności ciała staje \\ płynna dusza i udaje \\ ciało stałe nieco bardziej \\ twardo niż przeciętny twardziel $(. . .)^{\prime \prime 13}$
}

W tym opartym na lingwistycznej zabawie fragmencie postawione zostaje pytanie, które Kierc stawia wielokrotnie, a mogłoby ono brzmieć: „W którym miejscu kończy się dusza a zaczyna ciało?” Czy niedookreśloność obu tych kategorii nie wskazuje na ich współzależność, a tym samym właściwie uniemożliwia postawienie granicy między nimi? Ten paradoks zdaje się być nie do przezwyciężenia, bowiem poezja Kierca wikła się w dwie filozoficzne tradycje, z których czerpie pełnymi garściami: platońską i arystotelejsko-tomistyczna, wzbogacone niekiedy o myśl judaistyczną. Platonizm i opierające się na nim późniejsze różne gnostyckie i manichejskie nurty chrześcijaństwa nieortodoksyjnego, nakazujące bohaterom tej poezji ",wychylać się z ciała” (,jakbym nie miał ciała/ i jakby tylko dusza nago się wspinała"144), traktując je jako coś gorszego i odrębnego od duszy ${ }^{15}$. Natomiast Arystoteles, a później św. Tomasz z Akwinu, który rozwinął jego teorię, twierdzil, że „ciało jest substancjalnym wyrazem duszy, która dopiero w nim uzyskuje konkretną rzeczywistośc'”16. Stąd jasne jest, że ciało stanowi pewne medium, pośredniczy w komunikacji (u Kierca dotyczy to zarówno sfery antropologicznej, jak i transcendentnej). Równocześnie dusza zależna jest od doznań ciała, realizuje się w tej mierze, w jakiej współuczestniczy w cielesnym świecie, biorąc udział w zmysłowej relacji międzyludzkiej ${ }^{17}$. Ten kierunek myślenia przyjęła teologia ciała, bardzo bliska poetyckim wyobrażeniom ciała w twórczości wrocławskiego poety.

Mając więc do czynienia z tak skomplikowanym filozoficznie obrazem ciała, ukuty przez samego poetę termin „,wychylanie się z ciała" nie może być jednoznaczny. W twórczości Kierca wydarza się ono wyłącznie w dwóch momentach: akcie seksualnym i doświadczeniu mistycznym. Najczęściej jednak to jedno doświadczenie rozpisane na nakładające się na siebie etiudy, jak w wierszu Jakby z ciała wyleciała ${ }^{18}$. Już w tytule, odwołującym się do średniowiecznej Skargi umierającego, podejmuje Kierc polemiczną grę z tradycją, wskazując na znany europejski topos duszy opuszczającej ciało ${ }^{19}$. Wędrówka duszy w utworze wrocławskiego poety nie jest jednak spowodowana śmiercią. Funeralny topos ulega modyfikacji, a punktem wyjścia staje się doświadczenie metafizyczne. Ciało opuszcza świadomość bohatera lirycznego, nazwana przez niego dusza, co sugeruje religijny kierunek interpretacji. Dusza opuszczająca ciało występuje w tej poezji w kilku wariantach: 1. jest to doświadczenie epifaniczne, 2. dusza wyrusza na spotkanie z Innym lub jej wyjście jest konsekwencją tegoż spotkania (ekstaza), 3. jej wędrówka, choć często kończy się spotkaniem, ma też wymiar poznawczy, translokacja pozwala zmienić punkt widzenia, 4. jest to metaforycznie przedstawiona podróż w czasie (wspomnienia), pojawiająca się nagle, w asocjacyjnym ciągu, 5. jako element metafizyczno-mistycznego doświadczenia pozwala na niezwykle intensywne przeżycia przemieniające człowieka.

Jest zatem tak, odwołując się do G. Batailléa, że ciało nie stanowi, jak w manicheizmie, przeciwieństwa duszy, ale miejsce, gdzie to, co duchowe się wydarza, jest miejscem epifanii. Ta integracja (tomistyczna) powoduje, że choć osobno, byty te wzajemnie na siebie wpływają, nie stanowiąc starotestamentalnej jedności, nie istnieją też w rozłączeniu. Umożliwia to erotyczne ciało. Erotyczne, to znaczy źródłowo otwarte na doświadczenie Innego ${ }^{20}$. Jednocześnie działa to również

13 Tenże, Narcyz w siebie wpatrzon przyjemnie, [w:] Tenże, Zaskroniec, dz. cyt., s. 16

14 Tamże, s. 12.

15 J. Kosiewicz w odniesieniu do całego chrześcijaństwa pisze o nurtach w teologii podważających pozytywne znaczenie ciała, mówiąc o orientacji orficko-platońsko-gnostyckiej; Zob. Tenże, Myśl wczesnochrześcijańska i katolicka wobec ciała, Warszawa 1998, s. 18-37, 52.

16 M. Niemczuk, Filozofia kultury jako filozofia ciała rozumianego transcendentalnie, [w:] A. Kiepas, E. Struzik(red.), Terytorium iperyferia cielesności. Ciało w dyskursie filozoficznym, Katowice 2010, s. 607.

17 Tamże.

18 B. Kierc, Cło, Wrocław 2008, s. 29-30.

19 Topos duszy opuszczającej ciało został omówiony m.in. w: J. Kott, „Lubo snem, lubo cieniem, lubo mara nikczemna”, [w:] Tenże, Kamienny potok. Eseje o teatrze i pamieci, Kraków 1991; K. Wyka, "Dusza z ciała wyleciała...", [w:] Tenże, Wedrujac po tematach, T. 2: Puścizna, Kraków 1971; M. Czermińska, Sen-śmierć-dotknięcie. W zwiazzu z wierszem Anny Kamieńskiej „Ciało”, „Zeszyty Naukowe Wydziału Humanistycznego Uniwersytetu Gdańskiego. Prace historycznoliterackie" 1989, nr 15, s. 155-166.

20 K. Matuszewski, Georges'a Bataille’a mistyczna partuza, [w:] Tenże, Georges Bataille - inwokacje zatraty, Łódź 2006, s. 167-222. 
w drugą stronę, gdyby nie to, że erotyczne doznania odbijają się w duszy, nie byłby możliwy rozwój życia duchowego. Jak pisał M. Merleau-Ponty „ciało jest gestem, całością ścieżek już wyznaczonych, władz już ustanowionych, osiąniętym dialektycznym podłożem, na którym dokonuje się przybieranie wyższej formy, a dusza jest sensem, który właśnie się w nim ustanawia" ${ }^{\prime 2}$.Źródłowo otwarte ciało doświadcza Innego, a dusza nawiązuje z nim po-rozumienie.

\section{Mistyczna PROWOKACJA}

Wrocławski poeta konsekwentnie od lat tworzy poezję ukazującą w sposób bardzo dwuznaczny, niekiedy bulwersujący i prowokujący, związki erotyki i wiary (zob. np. Engels und Puppe, Wielki czwartek). Wielokrotnie narusza religijne i obyczajowe tabu. Najbardziej szokujący obraz Boga, jaki się z tej twórczości wyłania, to młody chłopiec, nawiązanie do dwunastoletniego Chrystusa nauczającego w świątyni22 ${ }^{2}$. Młodzieniec-Bóg ukazywany jest w poezji Kierca jednocześnie jako obiekt fantazji seksualnych ${ }^{23}$, ideał niewinności, nieświadomy przewodnik po cielesno-duchowych rozkoszach oraz jako Chrystusowe alter-ego, pierwiastek boski, którego się poszukuje w sobie (Tyber z piaskiem) albo ten utracony dziecięco-młodzieńczy witalizm, nieskrępowany niczym, dający upust rodzącemu się (niewinnemu) seksualnemu napięciu (Jeszcze nie, Róża).

W dwuznaczny charakter prezentowania postaci Chrystusa-Chłopca-Młodzieńca wprowadza nas utwór Wszystko przez Niego:

„Gdybym nie kochał tego Żyda, do niczego bym się nie przydał;

gdybym nie wielbił tego Chłopca,

Planeta byłaby mi obca;

Młodzieńca gdybym nie pokochał,

słyszałbym tylko wciąz: woynocha!;

gdybym Mężczyzny nie miłował,

próżne by były moje słowa;

gdybym Krwi nie pił z jego rany,

nigdy bym nie był zakochany;

gdybym nie poznał smaku Ciała -

czego by dusza moja chciała? (...)"24.

Zaskakuje w tym utworze fakt, że szczególnie akcentowanymi atrybutami Chrystusa są: jego wyznanie, chłopięco-młodzieńczość i płeć. Gdyby traktować ten wiersz wyłącznie jako dzieło konfesyjne (co mogą potwierdzać szczególnie aluzje Eucharystyczne), główną jego treścią byłoby podkreślenie przemieniającej (przebóstwiającej) i niezbędnej dla rozwoju duchowego człowieka miłości do Chrystusa. Zastanawia jednak, że ukazany w tym utworze ów Transcendentalny Młodzieniec właściwie bardziej przynależy do sfery ziemskiej niż religijnej, do profanum aniżeli sacrum (mowa jest chociażby o smaku ciała). Jasne jest zatem, że wiersz ten nastawiony jest na wywołanie szoku u odbiory, rzadko bowiem w tradycji chrześcijańskiej w związku z miłością Chrystusa podkreśla się jego płeć i cielesność. Utwór ten, podobnie jak wiele innych Kierca ${ }^{25}$, skupia się na adoracji męskości, męskiego ciała, z jawnie homoseksualną kodą , ,Gdybym się przy Nim Boga nie bał,/ Jakże bym poczuł, żejest z nieba?". Nakładające sięna siebie dwa porządki: seksualnego pożądania i namiętnej miłości do Boga, znak rozpoznawczy poezji wrocławskiego poety, zostają na koniec wyeksponowane. Bycie z mężczyzna, choć nieakceptowane przez Boga ${ }^{26}$, to

21 M. Merleau-Ponty, Structure du comportement, Paryż 1942, s. 226, [cyt. za:] M. Sarnińska-Górecka, dz. cyt., s. 13

22 Wskazać tu należy podkreślane mistyczne pochodzenie tych obrazów. W poezji Kierca odnajdujemy aluzje do doświadczeń mistycznych mistrza Eckharta, natomiast w prozie autobiograficznej uzupełnia je o dwie postacie: błogosławionego Henryka Suzona i Hugona von Hoffmanstahla, którzy również odwołują się do epifanicznej postaci młodego Jezusa, zob. B. Kierc, Bazgroły..., dz. cyt., s. 21-25.

23 Zob. Tenże, Engels i Puppe, Zaćmienie, [w:] Tenże, Zaskroniec, dz. cyt.; Tenże, Ośmioletni, Co z tego, Patrzenie (z Sarniej Skały), [w:] Tenże, Clo, dz. cyt.; Tenże, Czy ja umartem?, [w] Tenże, Plankton, dz. cyt.

24 Tenże, Cło, dz. cyt., s. 51

25 Zob. Tenże, Rozstanie, Tobiasz i anioł, [w:] Tenże, Raz na zawsze, dz. cyt.

26 Najciekawiej kontekst zarówno homoseksualnej (w domyśle) winy, jak i rozbuchanego seksualizmu przedstawia utwór Wedlug świętego Jana ([w:] Tenże, Cło, dz. cyt., s. 21), w którym podmiot wyznaje m.in. „Na co Ci moje gadanie (...)/ łapanie zachwytem,/ co przyzwoite, co nieprzyzwoite - rozpatrywanie: przyjaźn czy kochanie (...)”, ,,sen unieważni dwuznaczność pragnienia”. Problematyka potencjalnej grzeszności miłości do chłopca będzie w tej poezji wracać raz po raz i silnie naznaczy próby miłosnego (i platońskiego) opisu relacji między mężczyznąi młodzieńcem (chłopcem).Zob. Tenże, Znów, [w:] Tenże, Cło, dz. cyt., s. 38.

OGRODY NAUK I SZTUK NR 2014 (4) 
jednak w wymiarze cielesnej bliskości, która dana jest przez Stwórcę, uświęca dwoje ludzi, otwiera ich na inny wymiar spotkania z Bogiem. Zatem owo „bycie z nieba” mężczyzny możemy rozumiećco najmniej dwojako, w kategorii daru z siebie, ważnej w kontekście teologii ciała Karola Wojtyły, w której to drugi człowiek staje się darem, dzięki któremu „,ja" dojrzewa do pełnej miłości oblubieńczej. Jednocześnie mężczyzna ten jest Bogiem, z którym mistyczne zjednoczenie nie może być inaczej opisane, jak tylko za pomocą słownika ludzkiej erotyki. Poezja autora Cła, dzięki niezwykłej plastyczności przesyconej zmysłowością (szczególnie ważne są tutaj: dotyk, wzrok, smak) ukazuje, że istniejące obok siebie i przenikające sięjęzyki mistyki i erotyki nie mieszczą się w ortodoksji, ponieważ karmiąc się indywidualnym doświadczeniem i najbardziej skrywanymi pragnieniami, wymykają się językowi powszechnego kultu.

Szczególny splot jezzyka religii i erotyki, powielany i przetwarzany według paradygmatu alegorycznych odczytan Pieśni nad Pieśniami i toposu (a także symbolu religijnego) Chrystusa-Oblubieńca, niejako z natury rzeczy implikuje wykroczenie. W pogaństwie, jak pisze G. Bataille, nieodłącznym elementem sacrum była transgresja, łącząca to, co czyste inieczyste. Chrześcijaństwo zdecydowanie odwróciło się od nieczystości. „Odrzuciło winę, bez której sacrum jest nieosiagalne, gdyż tylko pogwałcenie zakazu daje do niego dostęp ${ }^{\prime \prime 27}$. Idealnie czysta religia tym samym wyrzekła się też ciała, waloryzowanego wcześniej zdecydowanie negatywnie, wykluczając je na długi czas z horyzontu własnych zainteresowań. Istniała jednak nisza, w której i ciało i erotyka służyły duchowości - mistyka. W stosunku do tzw. normalnych praktyk religijnych wykroczenie par excellence ${ }^{28}$.

Transgresyjny charakter erotyzmu sacrum w poezji Kierca wypływa z potrzeby ujawniania wszelkich mechanizmów ograniczających człowieka (normy społeczno-religijno-kulturowe), jak i obalania schematów zachowań uznawanych jako religijne $\mathrm{w}$ celu poszukiwania nieograniczonej jedności z Bogiem. Opisy modlitwy, przeżywania sakramentów czy mistycznych uniesień niejednokrotnie są tu wzorowane na ludzkim akcie płciowym, w którym podkreślana jest, często w dość brutalny sposób, naruszana granica cielesności, „mojości" (,"wdzieram się", „wepchało się", „wbiję", „wtykał”, "Wcisnąl”, , "gwałcone niebo"). Gwałtowność, popędliwość, nieokiełznaność instynktów są w tej poezji synonimami „pełni życia" , kreatywności, twórczego nieopanowania, a człowiek musi nauczyć się z nich korzystać tak, aby zachowując swoją nieujarzmioną zachłanność bycia, jednocześnie nie zatracił swoich aktywności duchowych.

Próba wyzwolenia się ze sztywnej moralności jest także próbą przywrócenia wartości nie tylko ciału i seksualności, ale odarciu ich z fałszywej interpretacji grzechu pierworodnego. Poezja Kierca sakralizuje kontakt cielesny, w tym także seksualny. Mając świadomość przemijalności ciała i jego niedoskonałości, jednocześnie udowadnia, że bez jego udziału nie jest możliwy rozwój, wyjście poza własne egoistyczne doświadczenie. Tylko relacja z Innym, która wydarza się w ciele i poprzez ciało, może przemieniać. Ważne, że w równej mierze dotyczy to doświadczeń mistycznych, opisywanych językiem erotyki, jak i doświadczeń erotycznych, uwznioślających, uświęcających kochanków. Tym samym próbuje Kierc przywrócić bliskości fizycznej i nagości status niewinności, odrzeć go z patologii poczucia winy i wstydu. Odkryć i wyrazić piękno i naturalność ludzkiej intymności.

\section{NAgość CIAŁA - KENOSIS Boga - ŚWIĘTOŚĆ}

Niemal w każdej chwili uniesienia, ekstazy, doświadczeniu epifanii bohater twórczości wrocławskiego poety jest nagi, swoje i innych obnażenie rozumiejąc wielorako - cieleśnie: „,nagi, wydobyłem się/ na przestrzeloną świstem jawę"29, ,"nagi, zamknąwszy już powieki" ${ }^{\prime 30}$, ,"w ciele obnażonej żony ${ }^{\prime 31}$, metaforycznie: „,w moich oczach, ostruganym/ do naga, do na-

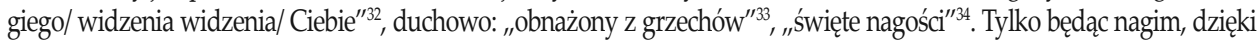
swojemu cielesno-duchowemu ukształtowaniu, chłonie świat i Boga całym sobą?

27 G. Bataille, dz cyt, s. 119.

28 L. Kołakowski opisuje trzy powody, dla których mistyka wiązała się z wykroczeniem przeciwko normom Kościoła: teologiczny, instytucjonalny i moralny. Zob. Tenże, Bóg mistyków. Eros i religia, [w:] Tenże, Jeśli Boga nie ma... O Bogu, Diable, Grzechu i innych zmartwieniach tak zzanej filozofii religii, Kraków 1988, s. 107-115.

29 B. Kierc, Raz na..., dz. cyt., s. 5.

30 Tenże, Plankton, dz. cyt., s. 40.

31 Tenże, Cło, dz. cyt., s. 33.

32 Tenże, Plankton, dz. cyt., s. 26

33 Tenże, Raz na..., dz. cyt., s. 27.

34 Tamże, s. 33 .

35 Zob. Tenże, Takie, [w:] Tenże, Rtęć, Wrocław 2010; Tenże, Błąd, [w:] Tenże, Zaskroniec, dz. cyt;; Tenże, Ośmioletni, Gołe, [w:] Tenże, Cło, dz. cyt. 


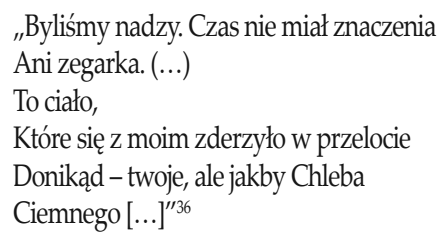

Nagość zatem jest dozwolona w sytuacji intymnej. Niewystawiona na widok publiczny, jest wzajemnym obdarowywaniem się, bliskościa, chęcią poznania swojej fizyczności. Sytuacja zbliżenia kochanków dzięki swej intymności, choć w percepcji podmiotu chce istnieć poza czasem, naznaczona jest jednak piętnem ulotności i przemijania. Wobec tego nagość jest tu symbolem erotycznym i kulturowym. Taka nagość pozwala na całkowite odsłonięcie przed Innym. Jest wyrazem zaufania, a także sygnalizacją otwartości ciała. Aby mogło dojść do zbliżenia (na poziomie fizycznym i duchowym) ciało zostaje obnażone, demonstrując swoją gotowość.

Jak pisze Giorgio Agamben, w naszej kulturze nagość łączy się ściśle z sygnaturą teologiczna, odsyłając w pierwszej kolejności do Księi Rodzajü. Wydarzenia w raju wiążą się w jego interpretacji z ostatecznym porzuceniem możliwości osiągnięcia czystej źródłowej nagości. Również teologia współczesna podkreśla fundamentalną zmianę, jaka zaszła w kontekście świadomości i nagości, jaka zaszła po zerwaniu owocu: „Biblijny autor demonstruje »smak « owocu z drzewa poznania dobra i zła nie na przykładzie samotności, ale na przykładzie nagości. Przed spożyciem owocu ludzie »Nie odczuwali wobec siebie wstydu« - nie znaczy, że nie posiadali świadomości własnej nagości (...) Nagość im nie dokucza. Po złamaniu zakazu zmienia się świadomość nagości. Nagość zaczyna ciążyćn ${ }^{\prime \prime 38}$.

Zakaz nagości jest zarazem niezwykle silny, jak i bywa kwestionowany ${ }^{39}$. W ponowoczesnej kulturze nadmiaru, przyjemności i konsumpcij ${ }^{40}$ coraz mniej odczuwa się wykroczenie nagości przeciw porządkowi społecznemu. Jednak nadal nagość w intymnym kontakcie dozwolona, w społecznym wywołuje konsternację.

Czym jest pozbawienie ubioru w poezji Kierca? Rozumiejąc je w duchu teologii interpretowanej przez G. Agambena, nagość w twórczości autora Cła nie jest czystą nagościa, czyli pozbawieniem zarówno ubioru w sensie fizycznym jak i szaty łaski, jaką obleczeni byli Adam i Ewa ${ }^{41}$. Natura ludzka od samego początku jest naga, jako „naga cielesność", potencjalnie narażona na działanie grzechu. Człowiek pozbawiony „nagiej cielesności” zostaje otulony w raju szatą łaski, którą stracił i zamienił ją na futro, zgodnie z tradycją przekazywaną m.in. przez św. Hieronima, symbolizujące śmierć. Radykalna metafizyczna zmiana natury ludzkiej dokonała się poprzez grzech, którego konsekwencją było „odkrycie ciała", postrzeżenie własnej nagoścíc ${ }^{42}$. Stąd natura nagości jest w istocie wadliwa, jest wynikiem jedynie braku laski. Tak rozumiana „naga cielesność” przeciwstawiona może byćjedynie nagości niewinnej (jużjednak nieźródłowej), rozumianej jako szata łaski. I właśnie do takiej nagości, waloryzowanej pozytywnie, niewinnej, nagości bez wstydu i zażenowania, tęskni bohater poezji Kierca. Stąd zapewne niejednokrotne odwołania do czystej niewinnej nagości dziecka i młodzieńca ${ }^{43}$, a przez to przetransponowane na niewinną nagość kochanków połączonych czystą miłością̇"

Nagośćjest symbolem istotnym dla poezji Kierca, dotyczy nie tylko ciała człowieka, ale „ciała Boga”, odwołując się do tajemnicy wcielenia oraz kulturowych norm prezentacii oblicza Stwórcy; potwierdza drogę obraną przez tę poezję, która przy próbach „wychylania się z ciała” podkreśla wagę wcielenia, paradoksalnie, afirmując świat, szuka innego, trwałego oparcia: „By móc kontemplować wieczne formy i uczestniczyć w istocie, trzeba przejść przez ciało. Nie ma innej drogi. W tym właśnie miejscu platonizm sprzeciwia się chrześcijańskiej wizji: platoński Eros dąży do odcieleśnienia, podczas gdy chrześcijański mistycyzm jest przede wszystkim miłością wcielenia i idzie za przykładem Chrystusa, który przyjął ciało, żeby nas zbawić. Pomimo tej różnicy obie postawy łączy wola zerwania ze światem i wstąpienia w inny. Platonik

36 Tenże, Znów, [w:] Tenże, Cło, dz. cyt., s. 38.

37 G. Agamben, Nagość, Warszawa 2010, s. 67.

38 M. Grabowski, Symbol „nagości” w historii upadku: fragment „antropologii adekwatnej”, [w:] Tenże (red.), Wstyd i nagość, Toruń 2003 , s. 231.

39 G. Bataille, Erotyzm, dz. cyt., s. 250.

40 Z. Bauman, Ciało i przemoc w obliczu ponowoczesności, Toruń 1995, s. 67-109.

41 W niniejszym akapicie streszczam postsekularna interpretację nagości Agambena. Zob. G. Agamben, Nagość, dz. cyt., s. 69-76.

42 W tym miejscu Agamben powołuje się na Teologie des Kleides Erika Petersona. Tamże, s. 69.

43 Zob. B. Kierc, Czy ja umartem?, [w:] Tenże, Plankton, dz. cyt., s. 40.

44 Zob. Tenże, Świt, [w:] Tenże, Cło, dz. cyt., s. 43.

OGRODY NAUK I SZTUK NR 2014 (4) 
wybiera drabinę kontemplacji; chrześcijanin, miłość do Boga, który - niewysłowiona tajemnica - przyjął ciało"45.

Bóg w poezji Kierca, poza erotycznymi kontekstami bywa również przedstawiany jako Bóg kenotyczny, ogołocony, a jego przedstawienia sprofanowane.

\author{
„Już się skończyło. Teraz obnażają \\ ołtarz; ściagnęli obrus byle jak \\ (nie są świadomi tego, że to znak \\ innego zdarcia szat i nie zwyczaju \\ ledwo pamiątka jest). Obok ołtarza \\ chłopcy zdejmują komeżki; w czerwonych \\ niby sutannach sa, przed Obnażonym, \\ kardynałami o dziecięcych twarzach \\ albo ptaszkami, które w Jego ranach \\ zatopią dzióbki jutro, gdy całować \\ przyjdą krucyfiks. Lecz teraz rozmowa \\ przy rozbieraniu jest nieokiełznana \\ (wędzidłem? Taktem? Czego chcę?); szczebiocą \\ śmiało, bo nie ma Go w tabernakulum. \\ No i co z tego? Nic. To, że do bólu \\ Czystego stoi wśród nich ogołocon" ${ }^{\prime \prime 4}$.
}

W utworze tym poeta zderza ze sobą prawdy teologiczne z wrażliwością obserwującego, znów nakładając na siebie kilka planów: liturgiczny (Msza święta, ołtarz, ministranci), teologiczny (Wielki Czwartek i zapowiedź Męki, kenosis), sytuacyjny (obserwacja wydarzeń po liturgii), interpretacyjny (ocena „profanacyjnych” zachowań). Wielość odniesień czyni ten wiersz skondensowanym traktatem teologiczno-moralnym, a ogołocenie Chrystusa głównym polem odniesienia. Obnażenie ołtarza jest czynione bez uwagi, bez zastanowienia nad stosunkiem przedmiotów liturgicznych do prawd boskich. W interpretacji bohatera Kierca jest to akt wymierzony w samego Chrystusa, niejako powtórzenie wydarzeń z Wielkiego Piątku, centralnych dla katolickiej nauki o zbawieniu. Prawda o wcieleniu Chrystusa, a potem dobrowolnym ukrzyżowaniu, jest zagadnieniem, z którym teologia radzi sobie z trudem, musi bowiem zaakceptować fakt, że Chrystus Syn Boży i Chrystus-Człowiek jest tą samą Osoba, a zatem jest Bogiem, ze wszystkimi jego atrybutami, wszechmoca, wszechwiedza, doskonałościa, a zarazem człowiekiem: cielesnym, niedoskonałym, choć nie naznaczonym grzechem. Fakt wcielenia, dzięki któremu Bóg stał się tak bliski człowiekowi, jest jednocześnie Jego ogołoceniem, spotęgowanym potem przez śmierć krzyżową. Kentotyczny Chrystus jest bardzo bliski bohaterowi poezji Kierca. Bliskość ta skupia się na podobieństwie ciała, które tak samo odczuwa i umożliwia bliskość niedostępną dla człowieka stającego wobec bezcielesnej i nieogarnionej Transcendencji. Bóg ogołocony, to Bóg cierpiący, z którego ranami można zidentyfikować własne cierpienie. Wreszcie to Bóg, którego poniżanie dokonuje się ciągle, nawet w jego emblematach ${ }^{47}$. Sacrum dotyczy tu zarówno ich warstwy materialnej - można je dotknąć, a tym samym podziwiać, adorować, albo poniżyć, wychwalać albo profanować, jak i warstwy znaczeniowej - teologicznych prawd, które objawia. Poruszony bohater chce się zjednoczyć z ciałem Chrystusa, tak jak mistycy - odczuwać i cierpieć to, co On. Jest to obraz tego rodzaju komunii, wspólnoty ciał i cierpienia, który swoją kontynuację znajduje w erotykach i lirykach eucharystycznych.

\title{
KOMUNiA (OSÓB, CIAŁ, Eucharystia)
}

Wywrotowy charakter tej poezji bierze się nie tylko z estetyki prowokacji, reinterpretacji prawd religijnych, ale również z idealizmu, z tęsknoty człowieka za tym, co będzie odpowiadało jego najskrytszym pragnieniom i wyobrażeniom, niezależnie od rzeczywistości. Sakralizując erotykę, Kierc nie porzuca wiary, że zjednoczenie jest możliwe. G. Bataille pisze, że to, co w erotyzmie doprowadza do skrajnej intensywności, nakłada na nas jednocześnie przekleństwo samotno-

45 O. Paz, Podwójny ptomień. Mitość i erotyzm, Kraków 1996, s. 218.

46 B. Kierc, Wielki czwartek, [w:] Tenże, Cło, dz. cyt., s. 27.

47 Zob. Tenże, Wniebowstapienie, [w:] Tenże, Cło, dz. cyt., s. 39. 
ści $^{48}$. Wrocławski poeta, wbrew teoriom francuskiego filozofa, pokazuje, że najintensywniejsze jest właśnie owo nasycenie zjednoczeniem. Ten niezwykle wyidealizowany obraz kontaktu z Bogiem (i partnerem seksualnym) istnieje uchwycony przede wszystkim w momencie ekstatycznego doznania, seksualnego przekraczania bariery , ,ja", a przez to wychylania się ku Innemu, ku jego ciału i duszy (człowiek), ku jego istocie (Bóg). Stąd takie kategorie jak , ,ja” i „ty”, ",moje” i „nie moje", „,ciało" $i$ „,dusza” właściwie zaczynają tracić na znaczeniu, bowiem najważniejsze jest doznanie jedności.

Patos przedstawiania intymnej relacji kochanków każe też zwrócić uwagę na jeszcze jeden aspekt, o którym pisał Przemysław Czapliński-niekompletność cielesnych przedstawieńn ${ }^{49}$. Kierc uwzniośla cielesny kontakt, ujawniającjego ograniczoność i chwilowość, a także niepełność. Szczególnie ujawniają to te wiersze, które w estetyce wzniosłości (ze szczególnie wyraźną stylizacją biblijną), próbują ukazać niekompletność fizyczności i konieczność dopełnienia przez transcendencję:

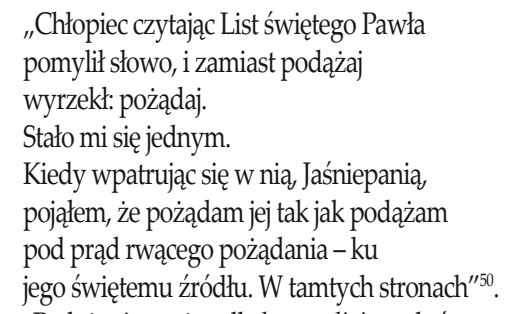

Podążanie, ważne dla homo religiosus, który w swym życiu stara się chodzić ścieżkami wyznaczonymi mu przez Boga, w wyniku pomyłki (freudowskiej?) staje się jego anagramem - pożądaniem, niejako rewersem chrześcijańskiej postawy. Podążanie-pożąadanie nie jest u Kierca jedynie grą słów, poeta zderza ze sobą dwie postawy, wierności i wykroczenia, opanowania i namiętności, nakazów „Idź za mną!” i „Nie pożądaj!”, stabilizacji i „rwącego prądu”. I, jak to bywa w prywatnej teologii poety, obie postawy, choć antagonistyczne, wzajemnie się dopełniaja, budując janusowe oblicze człowieka poddanego dwóm życiodajnym dla niego siłom, własnej seksualności i wierze. Kierc nie wybiera z pomiędzy nich, nie każe swoim bohaterom żyć powściągliwie, czy rezygnować z gorliwości wiary, jego poezja stanowi próbę radykalnego połączenia erotycznych i religijnych pragnień, gdyż, choć brzmi to obrazoburczo, one prowadzą ",ku świętemu źródłu”. Bogdan Twardochleb prowadzi nawet dalej interpretację tego utworu: „Jednym z pojęć kluczowych dla opisu świata jest u Kierca pojęcie pożadania. Pożadanie nie jest przy tym identyczne z pokusa, bowiem rozumieć je należy w połączeniu ze słowem łaska. Pożąadanie jest z przyzwolenia Boga, danym człowiekowi przejawem siły twórczej, jest dążeniem do przezwyciężenia dychotomii świata, czyli do odtworzenia jego jedności. Nasz świat jest bowiem rozpołowiony, np. pomiędzy męskość i kobiecość, kulturę (historię) i naturę, cierpienie i odkupienie, kościół (kosmos, jasność) i chaos etc. Pożądanie ma charakter mistyczny. To siła, która znaczy tyle co »podążanie za przewodnikiem « $(. . .)^{\prime \prime 51}$.

Wiersz Te strony - tamte strony nie stanowi więc apologii zwierzęcego nieokiełznanego seksualizmu, wręcz przeciwnie, wskazuje, że pożądanie Boga i kobiety ma swą przyczynę ulokowaną w prawdzie o ludzkiej kondycji i wpisanych w niej dwóch trwałych jej komponentach: pragnieniu i braku. Próbując je wypełnić, powraca Kierc do nienowoczesnego zawierzenia językowi czerpiącemu z sily erotyzmu, która wypowiada brak Boga, ale nie jak pisał Foucault s. $^{52}$ żeby oznajmićjego śmierć, ale brak możliwy do wypełnienia.

W nasyconych seksualizmem i erotyzmem wierszach autora Cła Bóg nie umarł, odczuwanie jego braku, niedopełnienia, jest siłą napędową tej poezji. To wieczne nienasycenie daje się interpretować w kategoriach teologicznych. Epektasis, grecki termin pojawiający się w Liście do Filipian ${ }^{53}$ oznacza „sięgać, dążyć" - Ekteinozostai dodatkowo wzmocnione tutaj przedrostkiem epi-i tak powstał czasownik - Epekteinomai, od którego pochodzi rzeczownik epektasis oznaczający silne, niekończące się dążenie ${ }^{54}$. Termin ten szczególne znaczenie odgrywał w teologii Grzegorza z Nyssy, który podkreślał, że im bardziej chcemy zbliżyć się do Boga, im bardziej pragniemy go poznać, tym bardziej staje się on niepochwytny

48 G. Bataille, Świetość́..., dz. cyt., s. 359.

49 P. Czapliński, Ciało i wzniostość, [w:] L. Wiśniewska (red.), Między stowem a ciatem, Bydgoszcz 2000, s. 164.

50 B. Kierc, Te strony - tamte strony, [w:] Tenże, Dla radości, Szczecin 1992, s. 29.

51 B. Twardochleb, Pożądanie świata, "Nowe Ksiązik” 1993, nr 7, s. 48.

52 M. Foucault, Przedmowa do transoresii, [w:] Tenże, Szaleństwo i literatura. Powiedziane, napisane, Warszawa 1999, s. 48

53 Flp, 3,13.r To pewnie odniesienie biblijne, List do Filipian? [RB]

54 K. Majdyło, Nieustanne dążenie - epektasis, http://majdylo.blogspot.com/2013/01/nieustanne-dazenie-epektasis.html, 10.10.2013. Zob. Z. Abramowiczówna (red.), Stownik grecko-polski, T. 2, Warszawa 1958, s. 209.

OGRODY NAUK I SZTUK NR 2014 (4) 
i odległy. Nie oznacza to, że Bóg się oddala od człowieka, ale jakiekolwiek poznanie Boga, dane nawet w doświadczeniu mistycznym, jest z gruntu niepełne. Właściwie zamiast przybliżać nas do Tajemnicy, oddala nas od niej. Jean Danielou tłumaczył to jako dialektykę posiadania i ruchu, punktu i drogi, chociaż są momenty udostępniania jakieś cząstki wiedzy o Bogu (np. epifania), to przez to, że nasza wiara jest ruchem w kierunku Boga, odsłaniają one nieskończoną przepaść między tym, co dostępne jest naszym rozumem, a tym, czym Bóg faktycznie jest..$^{55}$

Również dialektycznie pisze o epektasis Bogdan Trocha, podkreślając, że w tym jednym aspekcie poszukiwania i nienasycenia Bogiem mieszczą się dwa aspekty: „wyjścia z siebie” („wychylanie się z ciała” Kierca) i „wejścia w siebie” (samopoznanie $)^{56}$.W poezji wrocławskiego poety epektasis jest punktem dojścia, elementem wieńczącym nie tylko „metafizyczne głody", ale wszelkie zwielokrotnione pragnienia i pożądania zapisane w tej poezji. W odpowiedzi na brak i chęć jego wypehnienia, przez kobietę czy mężczyznę, inny świat-rewers świata snu, czy Boga znającego i dopowiadającego na cielesno-duchowe pragnienia człowieka, tworzy Kierc poetycką teorię komunii - potrzeby zjednoczenia.

\author{
„Zetknęliśmy się, albo to sen o sen \\ otarł się ledwie, że mogło śnić \\ o ciele ciało \\ już obnażone z tkliwych ograniczeń \\ skóry i chciwie czyhającej płci; \\ prawie go nie ma \\ poza tym bladym odbiciem, co niczym \\ byłoby, gdyby nie spijało krwi \\ Hostiami dwiema" ${ }^{\prime \prime}$.
}

Ciało i płeć traktowane są tutaj, nie po raz pierwszy zreszta, jako ograniczenie. Z podobną sytuacją mamy do czynienia w utworze Pobłyskiwanie, gdzie pojawia się wyrażenie „spławić płeć" ${ }^{\prime \prime}$, czy w utworze Za siedmioma górami, w którym czytamy: „Ciebie oddalonego o siedem/ potów, o płeć, o płot, o płotek" ${ }^{\prime \prime 5}$. Płeć jest zatem czymś wtórnym wobec ciała, ale równie jak ono stygmatyzuje i naznacza. Bohater poezji Kierca nie zgadza się na prymat płci, zwłaszcza w kontekstach erotyczno-miłosnych. Ideałem staje się zatem platoński androgyn ${ }^{60}$ czy też starotestamentalny adam, jedno, które jest początkiem i źródłem wtórnej wielości. W Księdze Rodzaju w opisie stworzenia świata, polisemiczny hebrajski rzeczownik adam użyty jest w znaczeniu „człowiek", czyli przedstawiciel rodzaju ludzkiego bez specyfikacji na płeć'. Jest zatem określeniem źródłowejjedności, która po stworzeniu Ewy została rozbita na dwie dopełniające się części. Androgyn-adam jest zatem wyobrażeniem Pierwotnej Całości, synonim dążenia do jedności, doskonałości, na wzór boskiej Pełni. Androgyn-adam to człowiek doskonały, łączący w sobie dwoistość płci.

Miłość androgyniczna byłaby o tyle doskonalsza, że dążąca do zniesienia różnicy, który raz to ukazywany jest jako przeszkoda (Inny, którego nie można doskonale poznać), raz jak coś pociagającego (Inny-kobieta zdumiewa swoją różnościa, pociąga, dopełnia; Inny - przez swoją różnicę pozwala budować własną tożsamość).

Miłość cielesna, ludzka, dzięki wymiarowi komunii osób, zjednoczenia aż po kres, jest zapowiedzią innej, głębszej miłości. Ciało i zjednoczenie cielesne jest święte, bo „zwiastuje” inną miłość, Boga do człowieka. Komunia [łac. communio, grec. koเvavía (koinonia)] dotyczy zarówno wymiaru wspólnotowego kochanków, wspólnego obdarowywania się, a idąc za oryginalnym greckim źródłosłowem obecnym w Biblii, znaczy wspólne życie w ogóle, czy komunię-wspólnotę tworzoną z poszczególnych grup, w tym najbardziej niezwykła, wytworzą między Żydami i poganami, jak i jest to odniesienie eucharystyczne - do komunii Ciała i Krwi Chrystusa, a także uczestniczenie w boskim objawieniu i samym Bogu, relację

55 J. Danielou, Platonisme et theologie mystique, Paryż 1944, s. 305-307, [cyt. za:] http://www.members.shaw.ca/jgfriesen/Definitions/Epektasis html, 10.10.2013.

56 B. Trocha, Między potępieniem a przebóstwieniem, czyli mitość w polu wartości, [w:] L. Wiśniewska (red.), Literatura w kręgu wartości, Bydgoszcz 2002, s. 388 .

57 B. Kierc, Komunia, [w:] Tenże, Szewski Poniedziałek, Wrocław 2005, s. 21.

58 Tenże, Plankton, dz. cyt., s. 9.

59 Tamże, s. 19.

60 Ciekawe, że sam poeta nie akceptuje androgynicznej interpretacji zróżnicowania płci. Zob. Tenże, Bazgroły..., dz. cyt., s. 29-32.

61 A. Gomola, Niejednoznaczna Biblia. O ttumaczeniu terminów polisemicznych, „Znak” 2013, nr 6 (697), s. 89. 
między człowiekiem a Bogiem ${ }^{62}$. Komunia jest zatem najpełniejszym z możliwych zbliżeń, przezwyciężająca śmierć, $w$ wymiarze ludzkim stanowi jedynie ideał, do którego się dąży, spełniając się w wymiarze mistycznym. Komunia-eucharystia, choć można w niej doszukiwać się analogii z mistycyzmem małżeństwa (jako antycypacja, zaczątek uczty zá́lubin Baranka zapowiedzianej w Apokalipsie ${ }^{63}$ ), jest zjednoczeniem głębszym niż czysto ludzki wymiar sakramentu małżeństwa.

Komunia ciał, osób i komunia z Bogiem stają się zatem punktem dojścia prywatnej teologii wrocławskiego poety. Obraz ciała, jaki się z niej wyłania, to ciało naznaczone skazą platońską i manichejska, ciało, którego należy się wyzbyć, które jednak w kontekście miłosnej komunii poddane zostaje sakralizacji (wyznaczanej przez estetykę wzniosłości, stylizację, aluzje biblijne i teologiczne, znane z Pieśni nad Pieśniami przeplatanie dwóch planów rozumienia: erotycznego i biblijnego). Ciało zaczyna znaczyćjako miejsce wydarzania się ludzkiej miłości, która jest obrazem miłości Boga. Tyko zatem sacrum miłosnego zjednoczenia może być jednocześnie doświadczeniem ludzkiej niewystarczalności, którą dopełnia mistyka, jak i obrazem zachłanności bycia, nieokiełznanej potrzeby odczuwania, nigdy nie zaspokojonej w chwilowym wymiarze życia ludzkiego.

\section{Bibliografia}

\section{Teksty źródłowe}

[1] Kierc B., Bazgroły dla składacza modeli latajacych, Szczecin, Brzeszcze 2010.

[2] Kierc B., Cto, Wrocław 2008.

[3] Kierc B., Dla radości, Szczecin 1992

[4] Kierc B., Plankton, Wrocław 2006.

[5] Kierc B., Raz na zazwsze, Wrocław 1997.

[6] Kierc B., Rtęć, Wrocław 2010.

[7] Kierc B., Szewski poniedziałek, Wrocław 2005.

[8] Kierc B., Zaskroniec, Wrocław 2003.

\section{Książki/artykuły}

[9] Abramowiczówna Z. (red.), Stownik grecko-polski, T. 2, Warszawa 1958.

[10] Agamben G., Nagość, Warszawa 2010.

[11] Bataille G., Erotyzm, Gdańsk 2007.

[12] Bataille G., Świętość, erotyzm i samotność, [w:] Z. Janion, M. Majchrowski (red.), Transgresje, T. 2, Gdańsk 1982.

[13] Bauman Z., Ciało i przemoc w obliczu ponowoczesności, Torun 1995.

[14] Bolecki W., Modernizm w literaturze polskiej XX wieku, [rekonesans], „Teksty Drugie” 2000

[15] Bromiley G. W., The International Standard Bible Encyclopedia: A-D, Michigan 1995.

[16] Czapliński P., Ciało i wzniosłość, [w:] L. Wiśniewska (red.), Miedzy stowem a ciałem, Bydgoszcz 2000.

[17] Czermińska M., Sen-śmierć-dotknieccie. W zwiazku z wierszem Anny Kamieńskiej „Ciało", „Zeszyty Naukowe Wydziału Humanistycznego Uniwersytetu Gdańskiego. Prace historycznoliterackie" 1989, nr 15.

[18] Danielou J., Platonisme et theologie mystique, Paryż 1944.

[19] Foucault M., Przedmowa do transgresii, [w:] Foucault M., Szaleństwo i literatura. Powiedziane, napisane, Warszawa 1999.

[20] Gomola A., Niejednoznaczna Biblia. O tłumaczeniu terminów polisemicznych, "Znak” 2013, nr 6 (697).

[21] Grabowski M., Symbol „nagości” w historii upadku: fragment "antropologii adekwatnej”, [w:] M. Grabowski (red.), Wstyd i nagość, Torun 2003.

[22] Kołakowski L., Bóg mistyków. Eros i religia, [w:] Kołakowski L., Jeśli Boga nie ma... O Bogu, Diable, Grzechu i innych zmartwieniach tak zzvane] filozofii religii, Kraków 1988.

[23] Kosiewicz J., Myśl wczesnochrzésijańska i katolicka wobec ciała, Warszawa 1998.

[24] Kott]., ,Lubo snem, lubo cieniem, lubo mara nikczemną, [w:] Kott J., Kamienny potok. Eseje o teatrze i pamięci, Kraków 1991.

[25] Matuszewski K., Georges'a Batailléa mistyczna partuza, [w:] Matuszewski K., Georges Bataille - inwokacje zatraty, Łódź 2006.

[26] Merleau-Ponty M., Fenomenologia percepcji, Warszawa 2001.

[27] Merleau-Ponty M., Structure du comportement, Paryż 1942.

[28] Niemczuk M., Filozofia kultury jako filozofia ciała rozumianego transcendentalnie, [w:] A. Kiepas, E. Struzik (red.), Terytorium i peryferia cielesności. Ciało w dyskursie filozoficzmym, Katowice 2010.

[29] Paz O., Podwójny płomień. Miłość i erotyzm, przeł. Fornelski P., Kraków 1996.

[30] Sarnińska-Górecka M., Ciało jako ontyczny fundament podmiotowości, Toruń 2012

[31] Trocha B., Między potępieniem a przebóstwieniem, czyli miłość w polu wartości, [w:] L. Wiśniewska (red.) Literatura w kręgu wartości, Bydgoszcz 2002.

[32] Twardochleb B., Pożadanie świata, „Nowe Ksiażki” 1993, nr 7.

[33] Wyka K., "Dusza z ciała wyleciała...", [w:] Wyka K., Wẹdrujac po tematach, T. 2: Puścizna, Kraków 1971.

\section{Netografia}

[34] Majdyło K., Nieustanne dążenie - epektasis, http://majdylo.blogspot.com/2013/01/nieustanne-dazenie-epektasis.html, 10.10.2013.

[35] http://www.members.shaw.ca/jgfriesen/Definitions/Epektasis.html, 10.10.2013.

62 G. W. Bromiley, The International Standard Bible Encyclopedia: A-D, Michigan 1995, s. 752.

63 Ap $19,1$.

OGRODY NAUK I SZTUK NR 2014 (4) 